\title{
STRATIGRAPHIC RELATIONSHIPS OF A MIOCENE MIXED CARBONATE-SILICICLASTIC INTERVAL IN THE BADAK FIELD, EAST KALIMANTAN, INDONESIA
}

\author{
James A. Hook* \\ Moyra E. J. Wilson**
}

\section{ABSTRACT}

The Sanga Sanga PSC in the Kutai Basin of East Kalimantan is host to several gas and oil fields with hydrocarbons principally reservoired in Miocene fluvio-deltaic channel sandstones. Limestones form only a subordinate lithology in this area and carbonate development is restricted both temporally and spatially. The thickest and most extensive limestones are in the uppermost $G$ interval of the Badak Field where several discrete horizons of limestones are interbedded with shales, sandstones and coals. Limestones exhibit an overall thickening upwards trend although individual limestones often display strong lateral variations in thickness and are notably absent from some wells. These limestones do not form reservoirs whereas laterally adjacent sandstones display similar production characteristics to carbonate-free intervals immediately above and below. An extensive blanket of thick shale in the basal $\mathrm{F}$ interval overlies this limestone bearing succession.

Previous models explain the lateral contrast in limestone thickness as the product of variable erosion and incision during sea level low stands. An alternative origin is proposed whereby limestones have developed marginal to coeval siliciclastic channel-mouthbar systems. Evidence includes the location of these carbonates within an overall transgressive regime with limestone deposition terminated by deepening or increased admixed fine siliciclastic input rather than exposure. Individual limestones typically pass upwards and laterally into shale mouthbar deposits rather than erosively-based sandstones and there is no evidence of carbonate lags that might reflect local erosion. It is suggested that the lateral variation in limestone thickness reflects

* VICO Indonesia

** University of Durham, UK their original patchy development. Coeval siliciclastic deposition, although concentrated at mouthbars and channel levees, was also dispersed throughout the carbonate patch reef deposits. The predominantly clay grade fraction within the carbonates strongly influenced the biota present and the development of the patch reefs.

This re-interpretation suggests that the poor reservoir quality of the carbonates reflects their overall transgressive nature and the high percentage of admixed fine grained siliciclastics. Alternative models fail to explain the paucity of secondary porosity that might otherwise develop during exposure in a tropical humid climate. Coeval shales may have provided argillaceous baffles that restricted the exchange of carbonate-bearing pore fluids into the coeval sandstones that have consequently retained reservoir quality.

\section{INTRODUCTION}

The Badak Field is a 7 TCF giant gas field in the Sanga Sanga PSC, East Kalimantan, Indonesia (Figure 1). Gas and associated condensate, together with minor black oil are produced exclusively from multiple stacked siliciclastic deltaic reservoirs. These were deposited during the Miocene in a similar fashion to sands and muds accumulating in the present day Mahakam River, and its associated delta, which provide a useful modern analogue for these reservoirs (Allen and Chambers, 1998). Carbonates are only locally developed in the area but have been described from both outcrop (Wilson and Lockier, 2002; Wilson, submitted) as well as the subsurface (Alam et al., 1999). The thickest development of carbonates in the Sanga Sanga PSC is in the upppermost portion of the $G$ interval within the Badak Field (Figures 1 to 5). From an exploration standpoint, these limestones are regarded as 
overburden, although a single well, Badak- 47, flowed minor hydrocarbon on DST $(0.597 \mathrm{mmscfgpd}$ and 12.7 bopd; Alam et al. (1999)). Overall, however, these limestones are regarded as 'tight'.

A fairly predictable degradation of reservoir quality with depth is observed within the deltaic reservoirs and this renders the sandstones below the $G$ interval (top ' $G$ ' $\sim-10,500$ feet TVDSS) as 'low perm'. Relatively few wells have been drilled to exploit the reservoirs below the limestones and low rates of penetration achieved through these carbonates has not encouraged a more extensive development of the deeper reservoirs, although lost circulation, a common obstacle in limestone intervals, has not been recorded.

Some 194 wells have been drilled on the Badak Field to date (August, 2003) but only 47 wells penetrate the uppermost $G$ interval, including these carbonates and their lateral equivalents. Several further wells reach TD within the uppermost $G$ interval, principally drilled to a sufficient depth to establish a correlation datum and to provide logging / completion sumps. A single well, Badak-103, has been cored through these limestones with further cores recovered in broadly coeval sandstones in wells Badak-89 and -104.

This study was initiated to explore the possible relationship of carbonate build-ups with a suspected syn-depositional deformation and trap generation, which might then be employed as a basis for mapping sandstone reservoirs within the field. Specifically, the younger D0050 / D0060 reservoirs show a strong congruence between channel geometry and dip on the southern flank of the field, suggesting an antecedent topographic influence on later channel orientations.

Little work has been done on these carbonates reflecting their poor reservoir potential. However, Alam et al. (1999), in reviewing carbonate reservoir development in the Kutai Basin region, do make specific reference to these carbonates, and interpret the observed lateral variations in carbonate thickness as being the product of variable incision, resulting from a subsequent sea-level low-stand. This current review challenges that conclusion and suggests that the observed lateral changes in limestone thickness are solely the product of depositional (constructional) processes. Recognition of these geometries as 'buildups' does not demand that changes in sea-level need be invoked for other lithologies to accumulate. This conclusion has important ramifications for the sequence stratigraphic interpretation and mapping style adopted in the overlying and underlying siliciclastic reservoirs that form the productive intervals of the field.

\section{STRATIGRAPHY AND CORRELATION}

The Badak Field comprises repeated sandstone-shale alternations, often capped by minor coals with rare limestones. Coals provide excellent correlation surfaces and in rare cases can be correlated fieldwide. It is useful to describe the interval bound by successive coals as a 'Parasequence', although these may not be the true equivalent of shallow marine parasequences for which this term was introduced (Posamentier and Allen, 1999). The development of an individual 'parasequence' may relate to relative sea level change, or to changes in sediment accumulation. Emery and Myers (1996) note that some workers relate similar cyclic deltaic deposits elsewhere to fourth order sequence stratigraphic cyclicity. However, more work is required before any such conclusion can be drawn from the Kutai stratigraphy studied herein.

In both outcrop and subsurface, coals appear to mark the abandonment of deltaic channels and typically display an asymmetric low gamma ray log response. These are referred to informally as 'low gamma' coals. The gamma response of these coals usually has a gradational base and sharp top. Based on long interval transit times recorded on sonic logs these lithologies are interpreted as coals rather than sandstone or carbonate horizons. Outcrop studies (Hook et al., 2001) note that such coals are typically black, vitreous, brittle with a blocky break along well developed cleats, and that their characteristic log motif reflects the development of an underlying seatearth. Such coals indicate periods of geomorphic stability when erosion and / or deposition were minimal. Coal deposition was typically terminated by abrupt flooding with a return to marine, usually distal mouth-bar, facies. In the lower part of the $G$ interval, however, these coals often pass upwards into a thin limestone, above which the typical shale-sandstone cycle is observed. Similar cycles are observed in other widely distributed deltaic deposits of various ages, for example the British Carbonifereous Yoredale Series (Elliot, 1975). 
Alternations of limestones, shales, sandstones and coals are observed in the upper portion of the $G$ interval, however, coals in this interval typically display a subtle difference in log character from those in the carbonate-free intervals described above. The coals from the upper portion of the $\mathrm{G}$ interval display a high gamma ray log signature, in conjunction with the long interval transit times recorded on sonic logs, in contrast with the 'low gamma' signature of coals from other lithologies. The high gamma signature of these coals gives rise to the informal term 'hot' coal, distinguishing them from the 'low gamma' coals. The 'hot' coals are typically thinner than their 'low gamma' counterparts and often display an asymmetric gamma ray log signature too, however, one in which the base is sharp and the top gradational. In outcrop, the 'hot' coals tend to be bown and non-vitreous, with an irregular texture that imparts a crumbly break, reflecting the paucity of cleats. Evidence of pedogenesis such as rootlets, pedoturbation and bleaching are lacking beneath similar coals in outcrop.

These 'hot' coals are regarded as the subsurface equivalents of the modern day detrital peat deposits, described by Allen and Chambers (1998) that develop on beaches of the Mahakam Delta that face the Makassar Straits. This latter type of coal, well developed in the upper $G$ interval, also provides a useful correlation marker. Other correlation markers include thin shales, typically developed at the base of thick, Coarsening Upwards (CU), shale intervals, often with a high gamma spike. These are differentiated from the 'hot' coals by their shorter interval transit times, as recorded on sonic logs, that are more typical of the interbedded shales. The coarsening upward shales are interpreted as condensed marine shales. The condensed shales, and the upper surfaces of the 'low gamma' coals and the 'hot' coals are all believed to represent Marine Flooding Surfaces (FS) that bound individual 'parasequences'.

The upper $G$ interval has been re-correlated employing these various surfaces. The naming scheme has attempted to follow the previous nomenclature, wherever possible, in order to permit comparisons with previous studies. The following key surfaces were recognised:

$\begin{array}{ll}\text { F0210.TZ } & \text { ('Hot' coal) } \\ \text { G0000.TZ } & \text { (Condensed Marine Shale) }\end{array}$

$\begin{array}{ll}\text { G001A.TZ } & \text { ('Hot' coal) } \\ \text { G001B.TZ } & \text { (Condensed Marine Shale) } \\ \text { G001C.TZ } & \text { ('Condensed Marine Shale') } \\ \text { G0020.TZ } & \text { ('Hot' coal) }\end{array}$

The '.TZ' suffix is the VICO abbreviation for 'Top Zone' and usually picked on the upper surfaces of both 'low gamma' and 'hot' coals.

The principal productive horizon over the studied interval comprises a sandstone within the G001A.TZ - G001B.TZ interval. This had previously been differentiated into two individual sandstones, the G001A and G001B sands. However, in the present study, these are considered to represent a single depositional unit that has been re-defined as the G0010 Sand. Rare wells also show sand development at the base of the G001C.TZ - G0020.TZ and G0000.TZ - G001A.TZ intervals.

Wells that penetrate the upper $G$ interval tend to fall into two broad groups. Approximately one third of the wells penetrate a significant thickness of carbonates in the G001B.TZ - G0020.TZ interval. The other wells record only minor limestones but correspondingly thick sandstones in the G0010 Sand within the G001A.TZ - G001B.TZ interval. In describing the carbonates, it is useful to differentiate the carbonates and G0010 Sand in the G001A.TZG0020.TZ interval from those in the G0000.TZ to G001A.TZ interval.

\section{DESCRIPTION OF THE G001A.TZ - G0020.TZ INTERVAL}

This interval comprises three separate units or 'parasequences' bound by candidate flooding surfaces:

$\begin{array}{ll}\text { - } & \text { G001A.TZ - G001B.TZ } \\ \text { - } & \text { G001B.TZ - G001C.TZ } \\ \text { - } & \text { G001C.TZ - G0020.TZ }\end{array}$

G001C.TZ - G0020.TZ

The lowermost unit, G001C.TZ - G0020.TZ is bound by the G0020.TZ 'hot' coal below and G001C.TZ condensed shale above. This unit comprises an almost universal basal limestone immediately above the basal G0020.TZ 'hot' coal. However, in some wells, a thin CU unit is recorded between the 'hot' coal and the limestone. This is typically argillaceous 
but in rare cases sandstones are recorded. The limestone displays a blocky to $\mathrm{CU}$ profile and displays marked lateral changes in thickness (Figures 3 and 4) reaching a maximum thickness of about 40 feet.

\section{G001B.TZ - G001C.TZ}

Broadly speaking, the overlying G001B.TZ G001C.TZ unit mirrors the lithologies and thickness changes observed in the underlying G001C.TZG0020.TZ unit described above with the thickest development of limestone tending to occur in the same wells (Figure 3). In these wells, the intervening G001B.TZ condensed shale is poorly expressed or absent, yielding an almost continuous limestone succession between the G001B.TZ and G0020.TZ surfaces, such as in Badak-86 (Figure 3). By contrast, wells Badak-84 and -103 (Figure 3), for example, display a marked shale break between the two units, representing the G001B.TZ surface, and both wells display well defined CU $\log$ motifs culminating in limestone.

Notably, however, limestone is absent from the G001B.TZ- G001C.TZ unit in several wells, for example Badak-77 (Figure 3) and the equivalent surface is often expressed by a relatively high gamma shale and / or deflection of the sonic logs. Thus, carbonates are areally less extensive in this unit than in the underlying G001C.TZ - G0020.TZ unit.

\section{G001A.TZ - G001B.TZ}

The uppermost interval, G001A.TZ - G001B.TZ, commences with the universal G001B.TZ condensed shale marking the base of a CU siliciclastic interval that culminates with the G0010 Sand. This interval is notably free of carbonate and is best developed where carbonates in the underlying G001B.TZ - G0020.TZ interval are attenuated (Figures 3 and 4). The thickness of the G001A.TZ - G0020.TZ interval as a whole tends to reflect the thickness of the G0010 Sand within this uppermost unit (Figures 3 and 4).

The thickest sandstones in this unit tend to display a sharp-based blocky or Fining Upwards (FU) log signature, as illustrated in wells Badak-83 and -157 (Figure 4). These pass laterally through thinner deposits with bow-shaped log signatures into thin ratty sandstones above thickly developed limestone in the underlying G001B.TZ - G0020.TZ interval
(Figure 3). Well Badak-79 displays thin discrete limestones at the top of both the G001B.TZ G001C.TZ and G001C.TZ - G0020.TZ intervals, whilst only vestiges of the former remain in well Badak-77 (Figure 3). However, both of these wells display thick CU deposits culminating in sandstone in the G0010 Sand (Figure 3). Well Badak-89 also displays a well expressed CU unit below the base of the G0010 Sand, notably, however, the G0010 Sand in this well is relatively thin with a blocky log motif and is overlain by a relatively thick shale unit below the G001A.TZ 'hot' coal (Figure 4).

These wells contrast with wells such as the Badak-86, -84 and -103 wells (Figure 3), in which limestones in the underlying G001B.TZ - G0020.TZ interval are thick. In response, this interval is thin and shaleprone in well Badak-86 and only slightly thicker in the Badak-84 and -103 wells where thin ratty sandstones form the G0010 Sand (Figure 3). Other wells, such as Badak-154 (Figure 4) display bowshaped serrated log motif, intermediate between these end-members.

A core taken in the Badak-103 well includes carbonates from the G001B.TZ - G001C.TZ and G001C.TZ - G0020.TZ intervals. This core is noteworthy for the detrital clay matrix between the bioclasts, as well as the lack of fracture and vuggy porosity.

\section{DESCRIPTION OF THE G0000.TZ - G001A.TZ INTERVAL}

The limestone in this interval tends to be universally present across the field and marked changes in thickness are also evident. However, there appears to be no obvious relationship between the thickness of limestone in this interval with limestone thickness in the underlying G001B.TZ - G001C.TZ and G001C.TZ - G0020.TZ intervals. This is illustrated in well Badak-77 (Figure 4) where a relatively thick limestone is developed in the G0000.TZ - G001A.TZ interval compared to the underlying G001B.TZ G001C.TZ interval, in which limestone is absent, with only a minor development in the underlying G001C.TZ - G0020.TZ interval. By contrast, well Badak-103 displays a thick development of limestone in the G001B.TZ - G001C.TZ and G001C.TZ G0020.TZ intervals but only an attenuated limestone is present in the G0000.TZ - G001A.TZ interval (Figure 3). This lack of correspondence is further 
illustrated by well Badak-84, which displays well developed limestones in all three intervals (Figure 3).

A weak control on the areal distribution of thickness and lithology is, however, suggested. Wells Badak48 and -79 (Figure 2) display two of the thickest limestone developments in the G0000.TZ G001A.TZ interval, and are notably located in northern and eastern locations, respectively. Wells Badak-84 and -50 (Figure 2) are unusual in that these display sandstones at the base of this interval. These wells are located in the western and southern portions of the field respectively.

Wells Badak-103 and - 79 (Figure 3) illustrate the marked thinning in the overlying F0021.TZ G0000.TZ interval where the limestone in the underlying G0000.TZ - G001A.TZ interval is particularly thick, as in well Badak-79.

\section{INTERPRETATION OF THE G001A.TZ - G0020.TZ INTERVAL}

Different wells afford glimpses of the entire spectrum of facies from an exclusively carbonate (with minor shale) end-member to a siliciclastic dominated endmember in which only minor limestones are present in the basal G001C.TZ - G0020.TZ interval. A composite section illustrating the step-wise changes between these two end-members has been assembled in Figures 3 and 4. However, it is important to note that this section comprises wells drilled in two or more coeval but different build-ups and their intervening siliclcastic deposits (Figure 2). Nonetheless, this illustrates well the overall thickening of the G001A.TZ - G0020.TZ interval associated with the progressive lateral change from limestone domination to sandstone domination

The first thick limestone development is in the G001C.TZ - G0020.TZ interval which is universally developed. These limestones display a strong lateral variation in thickness. They are capped by a condensed shale, the G001C.TZ FS, that separates them from a second 'parasequence' comprising the G001B.TZ - G001C.TZ interval, which is also dominated by carbonate. The lack of coarse grained siliciclastics between these successive 'parasequences' resulted in the G001B.TZ G001C.TZ deposition commencing upon a surface marked by topographic highs, inherited from the carbonate build-ups in the underlying G001C.TZ -
G0020.TZ interval. In the G001B.TZ - G001C.TZ interval carbonates preferentially nucleated upon earlier carbonate highs. Some wells such as Badak86 have near continuous development of carbonate throughout the G001B.TZ - G0020.TZ interval, giving rise to a blocky, aggradational, log motif. Elsewhere, the G001B.TZ surface is expressed as a discrete shale and the G001B.TZ - G001C.TZ interval is observed to coarsen upwards, often mirroring a coarsening upwards at the base of the earlier G001C.TZ - G0020.TZ interval, such as in the Badak-84 well. Notably, carbonates in the G001B.TZ - G001C.TZ interval appear to be areally less extensive than carbonates in the underlying G001C.TZ - G0020.TZ interval. This probably reflects topographic differentiation at this time with intervening water depths too deep for significant carbonate accumulation between shallow highs. These water depths may be estimated in the order of 30 to 50 feet. In clear waters these depths would not hinder carbonate development, but in the turbid waters of the delta, the photic zone would be considerably reduced and hence light-dependent carbonate production restricted to areas of very shallow water. The G001B.TZ surface is a condensed shale that marked the final flooding and inundation of the then well differentiated topographic highs.

The subsequent 'parasequence', G001A.TZ G001B.TZ, marked a pulse of siliciclastic sedimentation, possibly reflecting avulsion of the proto-Mahakam River and / or delta-switching. This is best expressed where the previous G001B.TZ G0020.TZ 'parasequences' are thin, between carbonate build-ups. Here the G001A.TZ G001B.TZ 'parasequence' is marked by thick, well developed, CU deposits overlain by sharp-based blocky or fining upwards sandstones, interpreted as a channelmouth bar system. The G0010 Sand (within the G001A.TZ - G001B.TZ interval) is channelised with infilling around individual carbonate build-ups in the underlying G001B.TZ - G0020.TZ interval by of channel units. There is no evidence to suggest that these channels eroded into the underlying 'parasequence'. Indeed, the intervening G001B.TZ condensed shale FS, marking the cessation of carbonate deposition in the earlier 'parasequence', is recognised in all the well penetrations. Furthermore, thick argillacous mouth bar deposits are always developed above attenuated limestones in the underlying G001B.TZ - G0020.TZ interval. Truncation of this limestone is unlikely, as attenuated 
limestones in the G001B.TZ - G001C.TZ 'parasequence' typically overlie similarly attenuated limestones in the underlying G001C.TZ - G0020.TZ 'parasequence', such as in well Badak-79, between which there is no intervening arenaceous deposits.

There is a marked change of facies within the G0010 Sand where it overlies thick carbonate build-ups in the underlying G001B.TZ - G001C.TZ (and G001C G0020.TZ) 'parasequence'. In these locations, the sandstone is usually thin and ratty. The latter are interpreted as crevasse splay or channel margin deposits. These thin sands were principally deposited during the latest stage of the G001A.TZ - G001B.TZ 'parasequence', when the intervening lows had been in-filled by the G0010 Sand mouth bar - channel complex. The sands also mark the time when even the thickest carbonate build-ups in the underlying G001B.TZ - G0020.TZ interval were finally inundated and 'over-run'.

It is noteworthy that there are no cases where sandstones directly overlye limestones, a feature that might otherwise be associated with erosion. Nor is there any evidence of tight streaks at the base of, or even within, the G0010 Sand, that might otherwise indicate lags of limestone clasts eroded from the carbonates in the underlying G001B.TZ - G001C.TZ (and G001C.TZ - G0020.TZ) 'parasequence'. The G0010 Sand appears to have been deposited between carbonate build-ups without eroding the former. It is therefore concluded that this took place within an overall progradational or transgressive regime. This agrees with the overall lithology evolution through the $\mathrm{G}$ interval which records a progressive thickening upwards of limestones.

The limestone within the G001B.TZ - G0020.TZ interval might easily be considered as a single continuous unit were it not for the evidence from wells such as Badak-84. In wells such as this there is a marked shale break as well as the $\mathrm{CU}$ nature from shale to limestone in both the G001C.TZ- G0020.TZ and G001B.TZ - G001C.TZ intervals. These limestones are interpreted as seeding upon incipient, possibly abandoned, mouth bar deposits that presumably afforded slightly higher elevations into shallower water, but still turbid waters. Wilson (in press) has previously noted the likely colonisation of mouth bars, elsewhere in the region, in this same fashion. Once developed these carbonates formed slight bathymetric highs, following post depositional compaction, for further colonisation by carbonate producers.

The vestigial limestones in wells Badak-79 and -77 represent the edge of the superimposed carbonate build-ups with the relief increasing from perhaps 20 to 30 feet during build-up development in the G001C.TZ - G0020.TZ interval to perhaps 40 to 50 feet in the G001B.TZ - G001C.TZ interval. These are post-compactional figures and actual relief at the time of accumulation is likely to have been significantly less than these values. The replacement of limestone deposits in these wells by an overlying coarsening upward interval, comprising mostly shale and siltstone, is interpreted as resulting from mouth bar progradation ahead of a fluvio-deltaic channel that ultimately deposited sediment between these earlier build-ups. The thin ratty sandstones in the G001A.TZ - G001B.TZ interval in wells Badak-86, -84 and 103 are interpreted as shallow channel margin or crevasse splay deposits that accumulated after the G0010 Sand had built out through, and over, the underlying build-ups. Alternatively, these may mark the abandonment of the channel system by subsequent transgression with a concomitant evolution to more distal argillaceous deposition.

The presence of thick shales in Badak- 89 above a relatively thin blocky G0010 sandstone may mark the edge of an attached side bar within the channel, in which an abandoned thalweg was in-filled by fines. This is analogous to the side-bars that focus sand in the modern Mahakam River (Allen and Chambers, 1998). The serrated bow-shaped log motif observed in well Badak-154 includes both mouth bar and overlying channel deposits, however, the lack of a sharp-based sandstone above the mouth bar deposits in this well suggests that the well was not located in the channel axis. Wells Badak-157 and -83 , by contrast, display a sharp, presumably erosive, base. In the latter, the underlying mouth bar is poorly expressed and this is interpreted as cannibalisation of the mouth bar deposits by the overlying channel as it built out across the mouth bar that it had previously constructed.

The relationships described and interpreted above are summarised in Figure 5. 


\section{INTEPRETATION OF THE G0000.TZ- G001A.TZ INTERVAL}

The interpretation of the passive infill of the topography between isolated carbonate build-ups in the underlying G001B.TZ - G0020.TZ interval by the G0010 Sand (itself in the G001A.TZ - G001B.TZ 'parasequence') is reinforced by observations from the overlying G0000.TZ - G001A.TZ 'parasequence'.

A 'hot' coal, the G001A.TZ surface, at the base of this 'parasequence' marks the abandonment of the G0010 Sand. Carbonates are variably developed in the G0000.TZ - G001A.TZ 'parasequence' above this coal, and, like carbonates in the underlying G001B.TZ - G001C.TZ (and G001C.TZ G0020.TZ) 'parasequence', these often display a CU upwards, or cleaning upwards, log motif, interpreted as carbonate nucleation upon earlier incipient mouth bar deposits. This limestone also displays the development of marked 'thicks', like those in the G001B.TZ - G001C.TZ interval. However, unlike in the latter, carbonates in the G0000.TZ - G001A.TZ 'parasequence' do not appear to have re-established themselves above earlier carbonates (i.e. areas of G001C.TZ - G0020.TZ carbonate development). This may reflect the absence of any marked topographic differentiation, following the submergence of relief inherited after the G0010 Sand, which effectively in-filled the topographic lows created by earlier carbonate build-up in the G001B.TZ - G0020.TZ interval. Furthermore, the overlying F0210.TZ - G0000.TZ 'parasequence' is a low Net / Gross interval with minor sandstone development confined to the uppermost part only. Again, there is no evidence of sandstones having eroded into earlier limestones to generate the observed changes in limestone thickness, and nor are there any 'tight' streaks in the F0210 Sand that might otherwise represent carbonate lag deposits eroded from the former. Strong thickness changes within this F0210.TZ - G0000.TZ interval may reflect onlap onto these carbonate build-ups. The overlying F interval marks a return to more typical deltaic reservoir deposition, without any significant limestone development.

The lack of correspondence between limestone thickness in this interval and that in the underlying G001B.TZ - G001C.TZ (and G001C.TZ - G0020.TZ) interval is thought to be due to the channelmouth bar system of the lower unit submerging any antecedent topography that might otherwise have led to the preferential nucleation of carbonates upon former carbonate build-ups. Indeed, it is noteworthy that the flooding surfaces marking the conclusion of carbonate build-ups (the G0000.TZ, G001B.TZ and G001C.TZ surfaces) always display a condensed shale character, whereas those marking the conclusion of siliciclastic dominated deposition (F0021.TZ, G001A.TZ and G0020.TZ) are marked by 'hot' coals. Widespread beach development, indicated by the 'hot' coals, only appears to have only taken place when the topography was subdued.

There is some evidence that thickness changes may reflect proximity to the contemporaneous depocentre within the G0000.TZ - G001A.TZ 'parasequence'. The thickest development of limestones is present on the northern and eastern fringes of the field. From this, together with the presence of a basal siliciclastic member in wells in the western and southern parts of the field, it is interpreted that the depocentre was located to the south at this time. Furthermore, the relief generated by build-up development in the G0000.TZ - G001A.TZ 'parasequence' was eliminated by argillaceous deposition in the F0210.TZ - G0000.TZ unit. The shale shows a marked thinning over areas of thick limestone development in this unit. This shale drape is considered to represent onlap of the build-ups, leading ultimately to the annealing of the earlier depositional topography, similar to the inferred covering of the depositional topography by the G0010 Sand (above).

The relationships described and interpreted above are summarised in Figure 5.

\section{DISCUSSION}

Overall, the limestones in the $G$ interval tend to thicken upwards from thin continuous isopachous horizons capping coals to thick but localised developments in the uppermost G0000.TZ G0020.TZ interval. These sometimes cap CU deposits that in rare cases include sandstones.

The upper $\mathrm{G}$ interval in the Badak Field displays a more marine character than elsewhere in the field. Limestones, which include coral and echinoderm bioclasts, reach their greatest thickness in this interval and are associated with condensed shales of probable marine character, together with $\mathrm{CU}$ deposits interpreted as mouth bars, and 'hot' coals that, by 
analogy with the modern Mahakam Delta, accumulated on delta front beaches. This contrasts with the majority of reservoirs in the field which tend to have poorly expressed mouth bars, rare condensed shales but common in-situ 'low gamma' coals, marking the punctuation of deltaic channel deposition by long periods of geomorphic stability. Limestones are also rare or insignificant in those intervals.

A previous study (Alam et al., 1999) concluded that the variable limestone thickness displayed [in the G001B.TZ - G0020.TZ interval] was the product of differential erosion during sea-level low-stand. Recorrelation and re-evaluation performed for this study, has led to a re-interpretation of these limestones as low relief build-ups within 'parasequences' that were deposited during in an overall transgressive regime. This model better explains the observed features including the presence and nature of field-wide flooding surfaces, without any sign of truncation, the absence of sandstone - limestone juxtaposition and the lack of carbonate lag deposits within the sandstones.

This also excludes the need to invoke multiple sealevel changes for the literally hundreds of other sharpbased channel sandstones encountered in the Badak Field. Only one sandstone to date, in the Sanga Sanga PSC, the G053B Sand in the Nilam Field (Butterworth et al., 2001), is a convincing example of an incised-valley fill.

\section{IMPLICATIONS FOR HYDROCARBON PROSPECTIVITY}

This uppermost $G$ interval is interpreted as the product of deposition within an overall transgressive regime with the G0000.TZ surface probably marking a Maximum Flooding Surface that concluded the end of carbonate deposition within a Transgressive Systems Tract. The opportunity for exposure in this overall transgressive regime was limited and there is no evidence to suggest karstification. Secondary dissolution porosity is lacking and aragonitic bioclasts in the Badak-103 core appear to have been replaced rather than leached. Transgressive carbonates of this nature do not appear to make attractive targets for hydrocarbon exploration.

Furthermore, the coeval detrital clay matrix of the carbonates due to deposition in a low energy turbid setting is likely to have hindered matrix microporosity development. The presence of this clay may also have reduced the competence of the rock and this may explain the lack of fracturing observed in this core and the absence of any lost circulation during drilling this interval. It is noteworthy that the one well, Badak-47, flowed minor oil and gas on DST. One of the authors has observed that oil is often produced from the tighter lithologies (more typically ratty sandstones) and this may reflect the residue of an earlier oil fill that was largely displaced by subsequent gas migration from all but the tighter lithologies.

Interstitial detrital clays and argillaceous mouth bar deposits appear to have effectively isolated sandstones and carbonates. These have restricted fluid exchanges between the carbonates and the broadly coeval sandstones favouring replacement of aragonitic bioclasts, without the development of secondary porosity, and shielded the associated sandstones from cementation by migrating carbonaterich fluids, maintaining the poroperm quality expected at this depth within the field. It is likely that these interbedded clays were only able to accumulate in the shallow water delta front areas because the overall energy regime of the Mahakam delta was low.

It was noted earlier that the G0010 Sand had previously been subdivided into two separate sands, the G001A and G001B sands. This earlier subdivision is thought to reflect earlier workers distinguishing sandstones with different log motifs. Typically a CU $\log$ motif is observed in the former G001A Sand, whereas the G001B Sand usually displays a blocky or FU $\log$ motif. It is now considered that this was an 'over-division' of sandstones that are otherwise genetically related. The 'two' sands are interpreted herein as a lower CU mouth bar deposit and its overlying blocky or FU channel sandstones. These 'two' sands are now considered to be in communication with one another, even where intervening shales are present.

This study also indicates that the location of carbonate build-ups does not appear to have an external control, at least not in this particular interval, that might have ultimately resulted in trap formation. Possible external controls might have included coeval tectonic doming associated with thrusting. This is useful to know when mapping the underlying and overlying deltaic reservoirs, which need not show any 
correspondence to the present-day structure of the field.

\section{CONCLUSIONS}

1. A mixed interval of carbonates and siliciclastics is developed in the uppermost $G$ interval of the Badak Field where carbonates are unusually thick (upto 50 feet). These display strong lateral changes in thickness which are re-interpreted as the product of local 'build-up' or patch reef development.

2. Carbonates typically overlie Flooding Surfaces marked by 'hot' coals or condensed shales that mark 'parasequence' boundaries. Where present, carbonate is typically the first lithology to develop above these flooding surfaces, preferentially nucleated upon mouth bar deposits, or earlier carbonate build-ups when intervening siliciclastic deposits are absent.

3. Variations in the thickness and location of carbonates in the G001B.TZ - G001C.TZ interval tend to mirror those in the underlying G001C.TZ - G0020.TZ interval, but the in the upper unit are arealy less extensive. The inherited depositional relief at the start of the G001B.TZ - G001C.TZ interval, from build-ups in the underlying interval, resulted in the preferential nucleation of carbonate build-up upon earlier ones.

4. The G0010 Sand is a mouth bar-channel system that accumulated between carbonate build-ups in the G001B.TZ - G0020.TZ interval and effectively submerged the inherited relief. This took place in an overall transgressive regime that did not favour exposure or erosion of the underlying carbonates. Sandstones never directly overlie limestone and there is no evidence of carbonate lags in the G0010 Sand channels.

5. Carbonates in the G0000.TZ - G001A.TZ interval show no relationship to those in the underlying G001B.TZ - G0020.TZ interval. This suggests that there is no external control on buildup development.

6. A thick shale overlies the uppermost carbonate unit and the G0000.TZ surface. It was this variation in carbonate deposition that was the basis for the original differentiation of the $\mathrm{F}$ and $\mathrm{G}$ sands within the field. The G0000.TZ surface is a candidate Maximum Flooding Surface marking the change from carbonate-rich transgressive deposition in a Transgressive Systems Tract to carbonate-free deposits in the overlying regressive High Stand Systems Tract.

7. This overall inferred transgressive regime did not favour exposure of the carbonates and accounts for the lack of secondary dissolution porosity. The coeval interstitial detrital clay matrix of the carbonates is believed to have reduced the competence of these carbonates, which do not respond to the intense folding of the region by fracturing.

8. Interstitial detrital clays and argillaceous mouth bar deposits isolated sandstones from carbonates. This restricted fluid exchange between the carbonates and the broadly coeval sandstones favouring replacement of aragonitic bioclasts without the development of secondary porosity, and shielded the associated sandstones from cementation by migrating carbonate rich fluids, maintaining the poroperm quality expected at this depth within the field.

\section{REFERENCES}

Alam, H., Paterson, D.W., Syarifuddin, N., Busono, I. and Corbin, S.G. 1999. Reservoir potential of carbonate rocks in the Kutai Basin region, East Kalimantan, Indonesia. Journal of Asian Earth Sciences, 17, p. 203-214.

Allen, G. P. and Chambers, J. L. C. 1998. Sedimentation in the modern and Miocene Mahakam Delta. Indonesian Petroleum Association. 236 p.

Butterworth, P. J., Cook, P., Ripple, R. A., Drummond, M., MacMahon, I., Kiesow, U., Setoputri, A., Dewanto, H. and Sidi, F. H. 2001. Reservoir Architecture of an Incised-Valley Fill from the Nilam Field, Kutai Basin, Indonesia. Indonesian Petroleum Association, Proceedings of $28^{\text {th }}$ Annual Convention, p. 537-555.

Elliot T. 1975. The sedimentary history of a delta lobe from a Yoredale (Carboniferous) cyclothem. Proc. Yorks. Geol. Soc., 40, p. 505-536. 
Emery, D. and Myers, K. J. 1996. Sequence Stratigraphy. Blackwell, 297 p.

Hook, J.A., Butterworth, P.J. and Ferguson, A. 2001. Contrasting Miocene Fluvio-Deltaic Channel Types from Perjuangan Quarry, East Kalimantan, Indonesia: Implications for Subsurface Reservoir Correlation. Proc. IPA 28th Annual Convention, p. 617-632.

Posamentier, H. W. and Allen, G. P. 1999. Siliciclastic Sequence Stratigraphy-Concepts and
Applications. SEPM Concepts in Sedimentology and Palaeontology \#7. $210 \mathrm{p}$.

Wilson, M.E.J. (submitted). Equatorial delta-front patch reef development during the Neogene, Borneo. Submitted to Journal of Sedimentary Research.

Wilson, M.E.J. and Lokier, S.J. 2002. Siliciclastic and volcaniclastic influences on equatorial carbonates; insights from the Neogene of Indonesia. Sedimentology, v. 49, p. 583-601. 


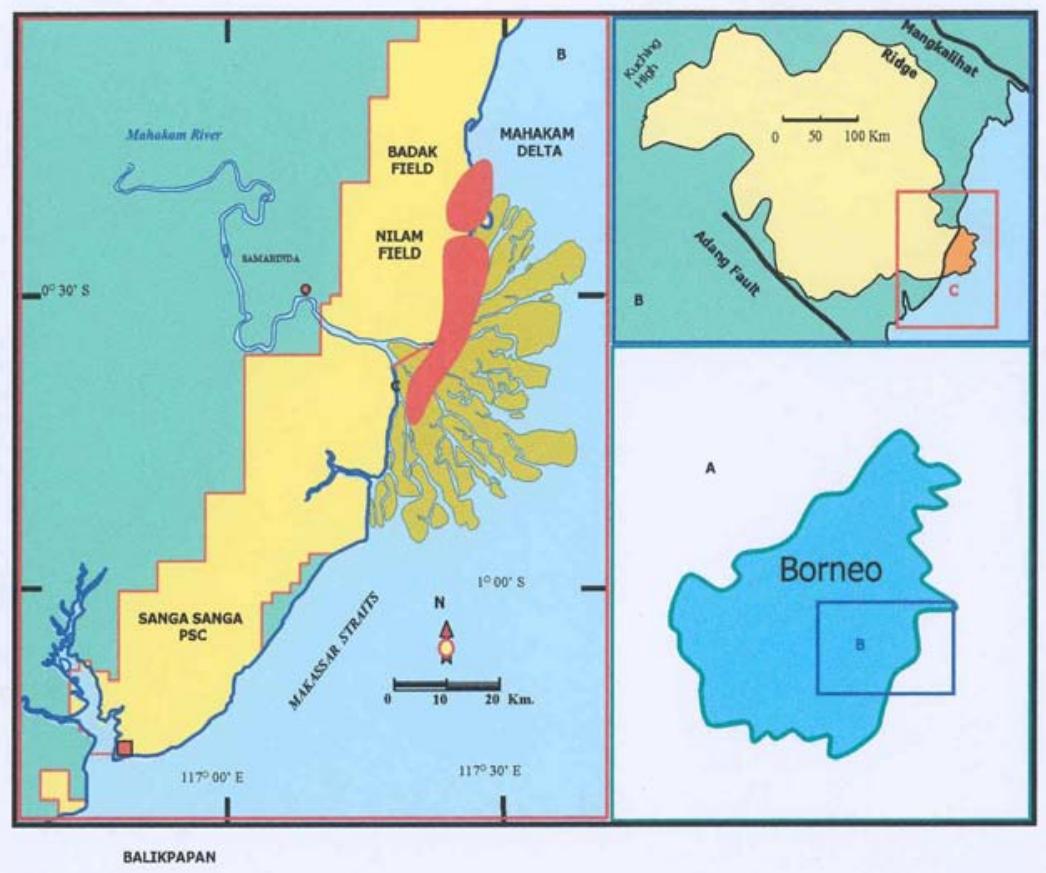

Figure 1 - Location of Badak Field.

A. Location of study area in East Kalimantan, Indonesia.

B. Regional structural elements controlling the extent of the (onshore) Kutei Basin.

C. Location of the Badak Field in the Sanga Sanga PSC.

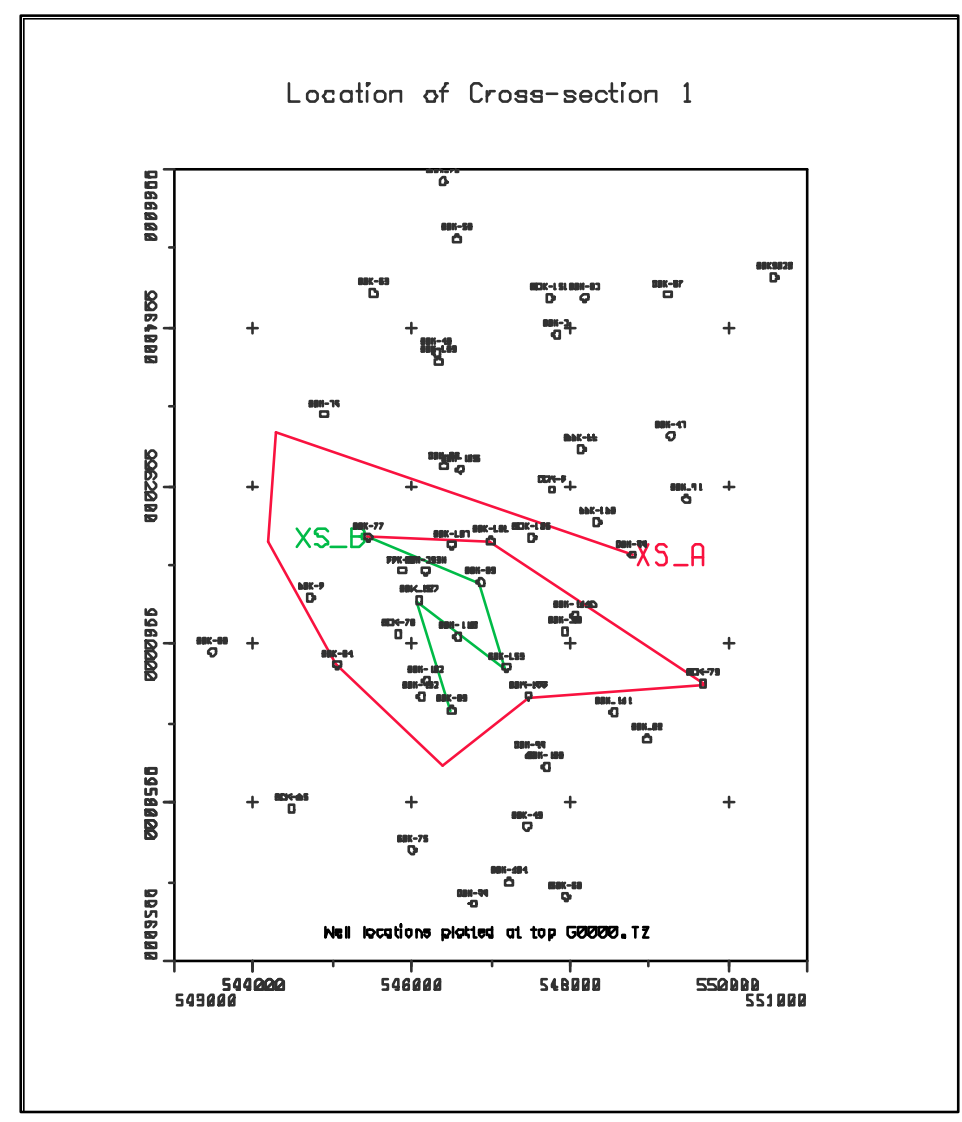

Figure 2 - Location of wells penetrating the whole of the ' $G$ ' interval in the Badak Field. XS_A refers to wells displayed in Figure 3 and XS_B refers to wells displayed in Figure 4. 


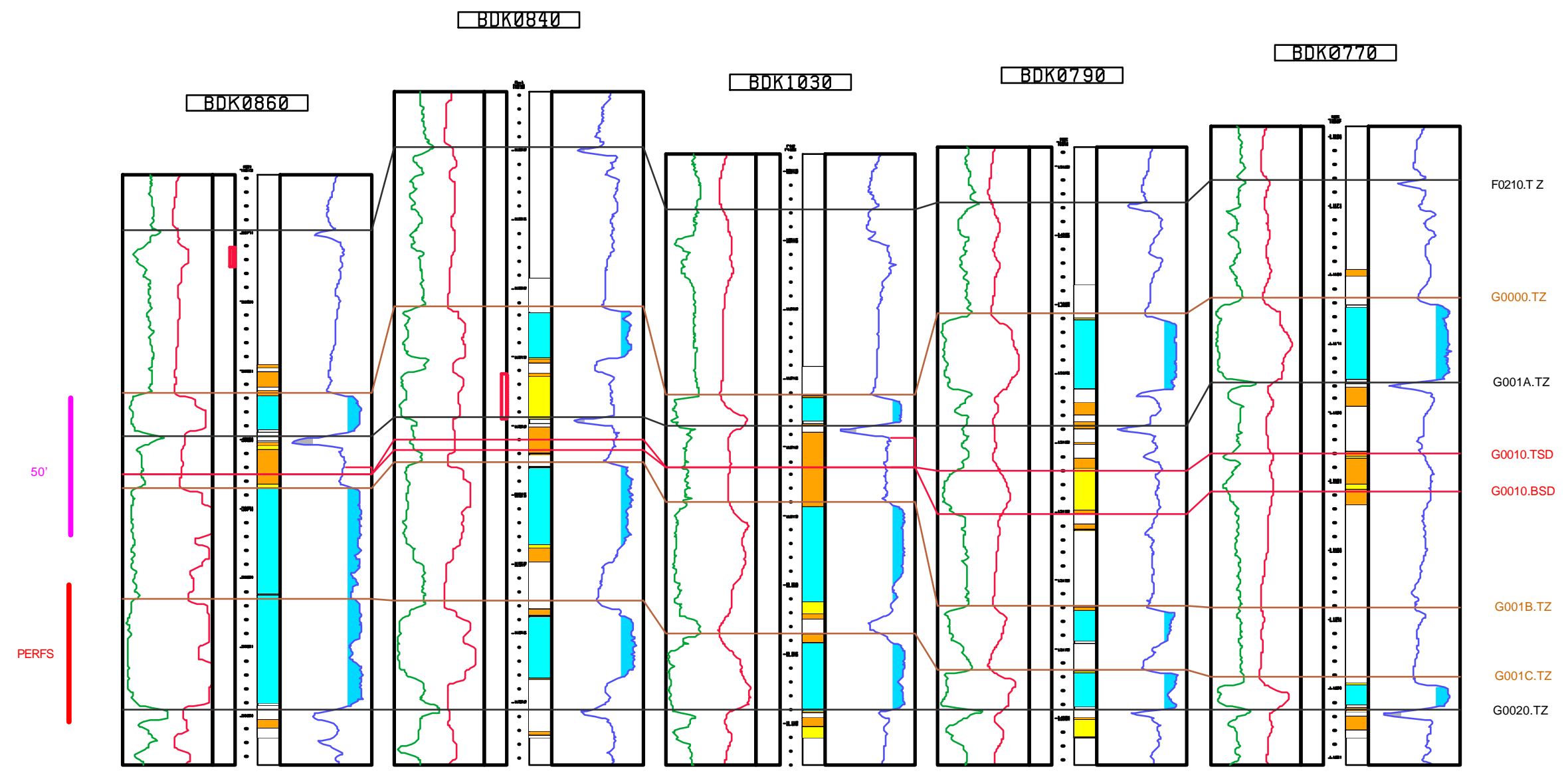

\section{Key to Well Logs}

LEFT GR: 0 - 150 | Resistivity: 1 - 1000 | Sonic: 140 - 40 RIGHT

Figure 3 - Well logs illustrating the probable spectrum of facies from the centre (left) through the edge (right) of an idealised carbonate build-up developed in both the G001B.TZ - G001C.TZ and G001C.TZ - G0020.TZ intervals. See cross-section line XS_A on Figure 2 for location of wells. 


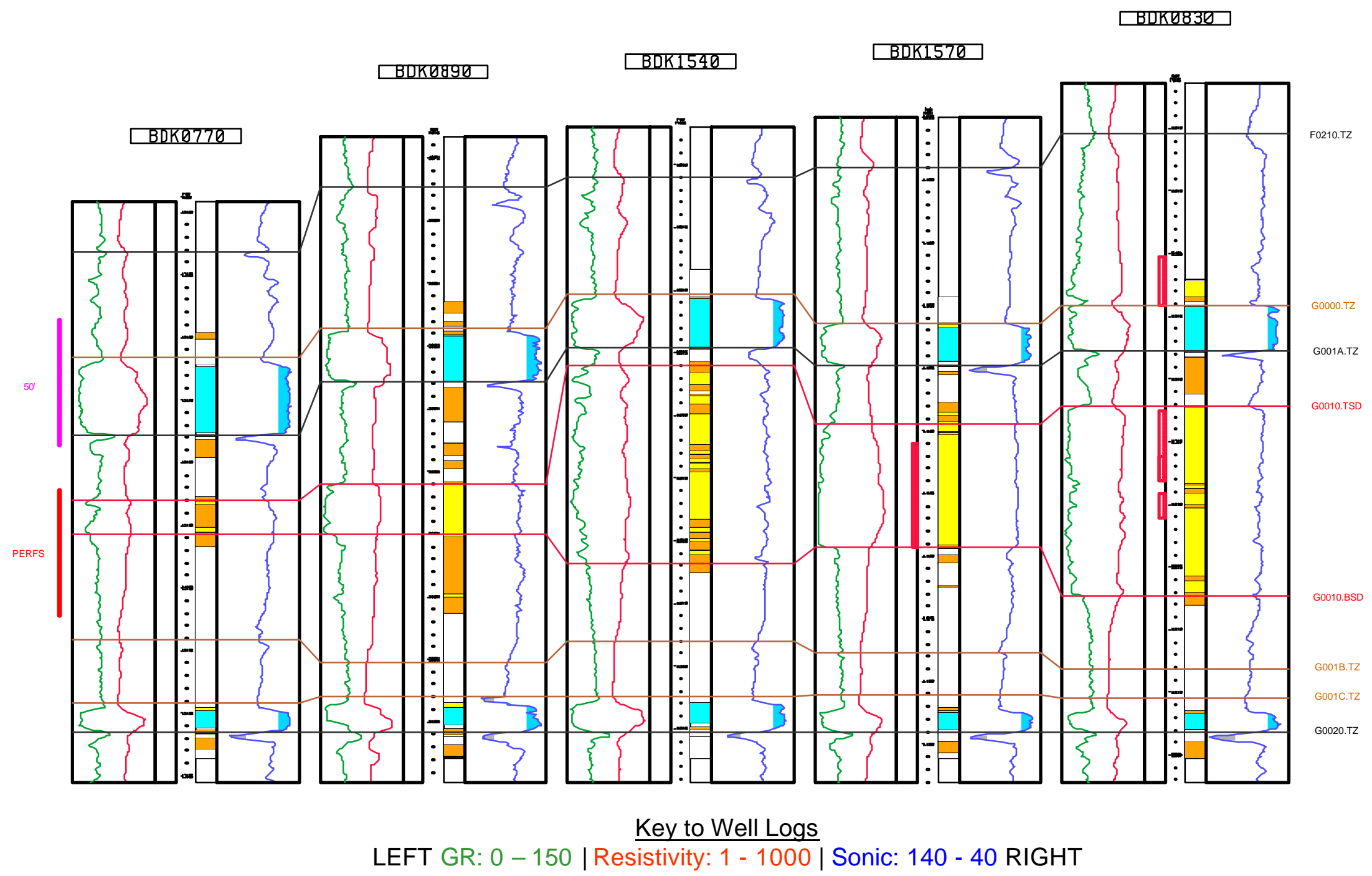

Figure 4 - Well logs illustrating the probable spectrum of facies from the edge (left) through the axis (right) of an idealised G0010 Sand channel mouth bar system developed in the G001A.TZ - G001B.TZ interval. See cross-section line XS_B on Figure 2 for location of wells. 


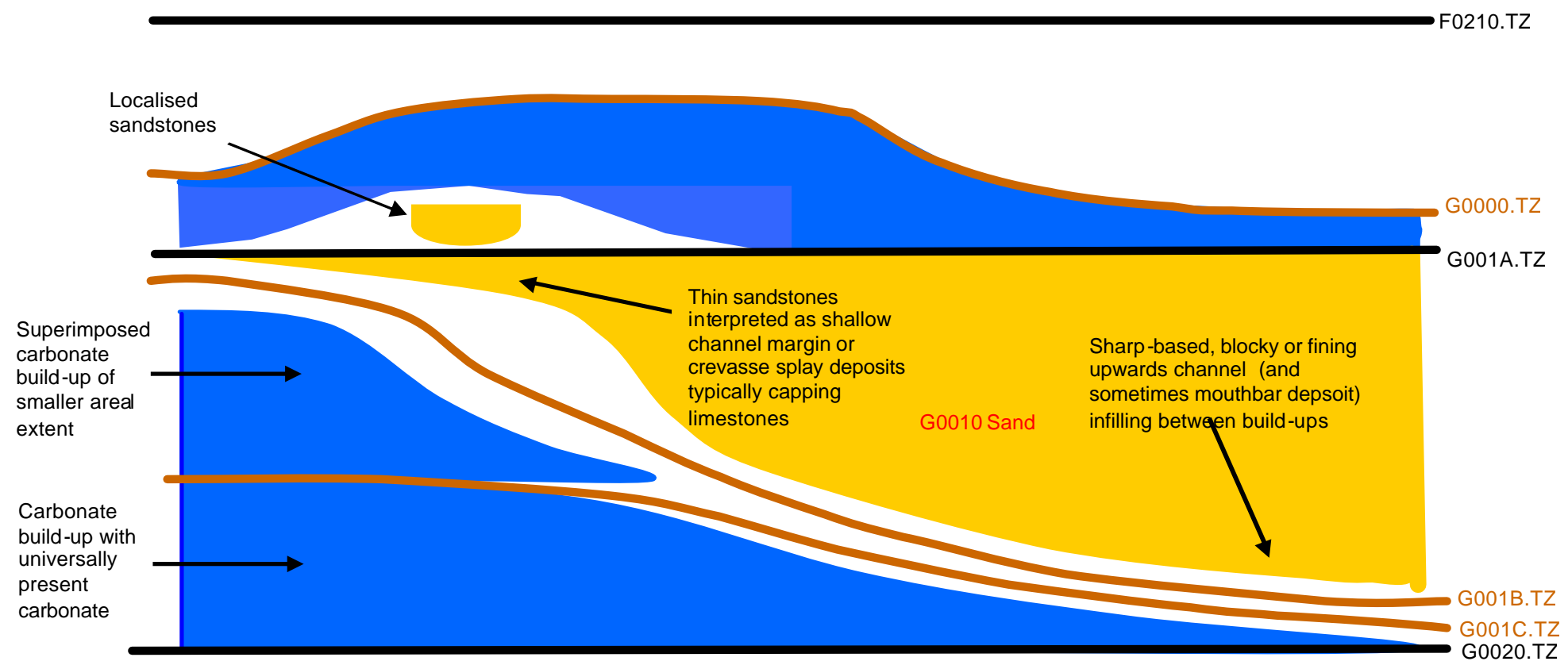

Figure 5 - Interpretation of stratigraphic relationships highlighted in figures 3 and 4. 